\title{
Correction to: Managing patient flows in radiation oncology during the COVID-19 pandemic
}

\author{
Reworking existing treatment designs to prevent infections at a German hot spot area \\ University Hospital
}

\section{Dennis Akuamoa-Boateng ${ }^{1}$ (D) $\cdot$ Simone Wegen ${ }^{1} \cdot$ Justin Ferdinandus ${ }^{2} \cdot$ Regina Marksteder $^{3} \cdot$ Christian Baues $^{1} \cdot$ Simone Marnitz ${ }^{1}$}

Published online: 15 December 2020

(c) The Author(s) 2020

\section{Correction to:}

\section{Strahlenther Onkol 2020}

https://doi.org/10.1007/s00066-020-01698-6

The original version of this article unfortunately contained a mistake.

Section "Patients and methods," fourth paragraph, first sentence, should read: All sorts of business trips were cancelled and personnel with transnational travelling history were required to abide by a 14-day campus access prohibition ruling.

The original article has been corrected.
Open Access This article is licensed under a Creative Commons Attribution 4.0 International License, which permits use, sharing, adaptation, distribution and reproduction in any medium or format, as long as you give appropriate credit to the original author(s) and the source, provide a link to the Creative Commons licence, and indicate if changes were made. The images or other third party material in this article are included in the article's Creative Commons licence, unless indicated otherwise in a credit line to the material. If material is not included in the article's Creative Commons licence and your intended use is not permitted by statutory regulation or exceeds the permitted use, you will need to obtain permission directly from the copyright holder. To view a copy of this licence, visit http://creativecommons.org/licenses/by/4. $0 \%$.

The online version of the original article can be found under https://doi.org/10.1007/s00066-020-01698-6.

Dennis Akuamoa-Boateng, MBA

Dennis.Akuamoa-Boateng@uk-koeln.de

1 Department of Radiation Oncology, Center for Integrated Oncology, University Hospital Cologne, Cologne, Germany

2 Department of Nuclear Medicine, University Hospital Essen, Essen, Germany

3 Department of Hospital Pharmacy, University Hospital Cologne, Cologne, Germany 